\title{
9. ELEMENTS OF IMPACT ON STUDENT TRAINING: AREAS OF COMPETENCE SPECIFIC TO MUSICAL EDUCATION
}

\author{
Viorica Crișciuc ${ }^{276}$
}

\begin{abstract}
The complex and integrated nature of issues such as globalization, migration, interculturality, environmental protection, information explosion, calls for a complex approach to musical education. In order to cope with the changes in the contemporary world, students need generic skills such as: the ability to learn how to learn, the ability to evaluate and solve problems. Analyzing the theoretical and methodological sources, the universal character of musical competences was investigated, investigating the classifications of different historical epochs of notorious personalities of the field and from the perspective of the main fields on which the Music Pedagogy (Psychology of Music and Musicology) is founded. This article denotes some aspects of the competencies specific to the training and education of students at the Music Specialty.
\end{abstract}

Key words: competencies specific, lifelong education, skills transdisciplinary musical education

\section{Introduction}

According to modern didactics, competences training passes the learning process through its specific mechanisms and forms an integrated set of knowledge, capabilities and attitudes. The 20th century provides us with the main features of conceptual didactics. The formative character of active pedagogy in didactics was announced much earlier in the Romanian educational space, sec. XX was already well established. Thus, in 1988, I.Bontaş states that "the student will not only be a receiver in the teacher's communication act, but will be the one who finds the truth by itself, using analysis, synthesis, comparison, abstraction, generalization and application of knowledge" [1, p.97].

In its turn, the general concept of formative education consists of various particular concepts, which represent it in its defining aspects. Knowledge. Lat. cognoscere - information. Knowledge is the cognitive component of learning and learning, expressed through information in the form of notions, concepts, ideas, theses, laws, principles, theories, hypotheses.

DEX defines the first two meanings of the word as totality of notions, ideas, information that someone has in any field. Contrary to the definition in the dictionary, Romanian, and not only, ossified the expression of teaching knowledge. But knowledge does not identify with information; they are acquired information, values of the person, this defining aspect of knowledge being evidenced even by authors of classical didactics such as I.Stanciu, Iu.Babanski, V.Kraevski, N.Naumov [2] and others. According to I.Bontaş, S.Cristea, C.Cucoş, I.Grigoraş and others, the knowledge (= content units) are designed in the context of teaching, the realization of which involves three complementary operations:

\footnotetext{
${ }^{276}$ Associate Professor PhD., „Alecu Russo” State University from Bălţi, Republic of Moldavia, email: vioricacrisciuc@gmail.com
} 
a) definition, which ensures the introduction of new knowledge in the act of teaching, with their concretization by describing some episodes, signs, symbols; b) to expose knowledge, to assert the defined knowledge, to compare and classify them by demonstrations, compositions, employing the opinions of the educated;

c) explanation, which assures the support of the didactic act by the procedural, teleological ordering of the knowledge transmitted at the level of pedagogical communication.

\section{Discussions}

A last-minute vision of knowledge, related to the concept of formative education and the principles of creation-artistic reception, advances V.Pâslaru [5, p.75], according to which, even in scientific knowledge, knowledge is very different from information (concepts, ideas, theses, laws, principles, theories, hypotheses) are marked by the personality of the connoisseur, the more they are personalized in the artistic and aesthetic knowledge where the truth of the knowledge is not in the outer universe of the knowledge, but as M.Heidegger [4] states, it is re-created, produced by the workman himself, so it is a truth in the area of the intimate universe of the educated subject.

Capabilities. Latin.- capacity. Skill, skill, skill, force to do something in a certain area. The possibility of having a body, a system, etc. to accumulate a quantity of matter or energy. The ability to work in a field, to achieve something. Capacity building is the core unit or the "Training" module, which is why many researches have been dedicated to this concept. In the capacity building, the student / student advances through successive abstractions from assimilation of knowledge to their application in diverse learning situations. In the sciences of education, the term capacity has a double meaning: a general sense which takes into account the general values of the individual - skills, behaviors, characteristic features, a narrow sense, which denotes a component of competence: skill, skill, skill [2, p. 26].

Attitudes. What does it mean to affirm your position. Attitude is the fundamental component of character. It is a mental, synthetic construction that brings together intellectual, affective, and volitional elements. Attitude is the internal position adopted by a person in relation to the social situation in which he is placed. It is constituted by the selective, relatively durable organization of different cognitive, motivational-affective psychic components and determines how one person responds and acts in one situation or another. Attitude is the base invariant to which the student / student selectively orientates, preferentially self-regulates, adapts evolving.

Only conscious, deliberate orientation, sustained by an interpretative, generalized, valorizing, justifiable function, only the stable, generalized, selfdirected reaction and grounded on his strong beliefs translates an attitude. After T.M. Newcomb, the attitude reflects the form in which the previous experience is accumulated, preserved, and organized in the individual when it approaches a new situation. Attitude appears as the link between the dominant internal 
psychological state of the person and the multitude of situations to which he relates in the context of his social life. The skills in the view of several scholars have a different level of generalization: the higher the class of objectives, the more general it is. Competencies are of different value, being grouped into:

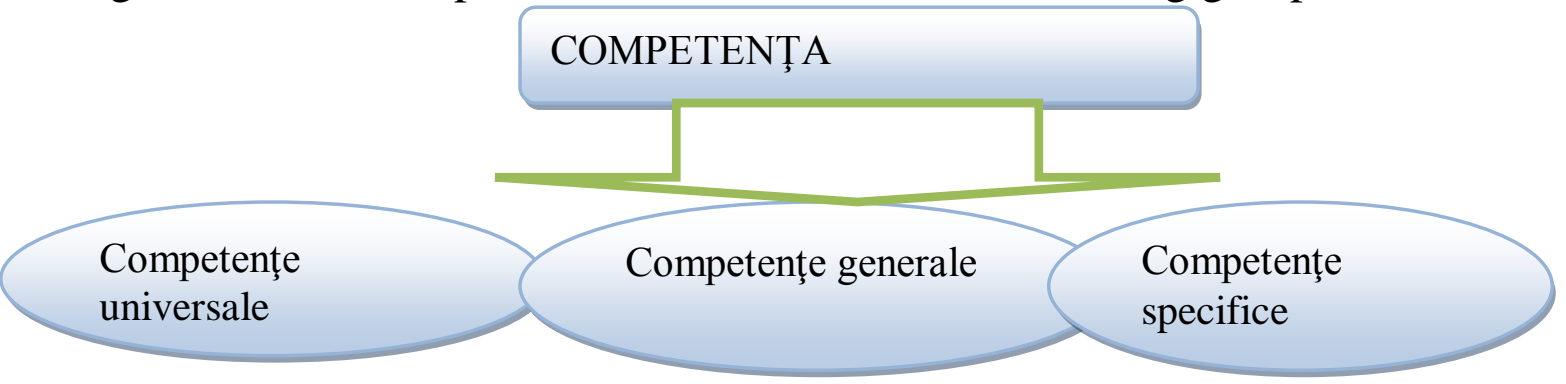

Fig. 2.3. General Classification of Competencies

1. Universal competencies - applicable and applicable in any kind or form of activity and structured by the European Commission in eight core competencies; 2. General skills - which manifest and form in a field of human knowledge or activity. Accordingly, according to the four areas of knowledge: ex. communicative-linguistic competence, artistic-aesthetic competence;

3. Specific competencies - achievable in a relatively narrow sphere, such as interpretative competence as a component of artistic-aesthetic competence.

Specific competences are defined in the fields of basic musical-didactic activities, in our case, in the field of Musical Education and are formed during a semester or school year. They are derived from general competences, being stages in their acquisition.

In the literature, three large groups of definitions of the concept of com- petence are specified.

1. Competence is viewed as the basic quality of the individual.

2. Competence is defined as an assessment / appreciation criterion for pupils, reflecting the idea of neoplasms, components of competence, seen as the results of the training.

3. Competence is seen as a measure to assess the student's professional training, the student proposes to interpret competence as an open system of knowledge, skills and skills, as the experience of the person, which is acquired throughout his or her life, right a conglomerate of professional knowledge and skills.

The best definition of competence is the Canadian researcher Philippe Jonnaert. In his opinion six elements constitute the semantic area of the notion of competence:

1. Competence is always associated with a situation; this situation is part of a family of situations, the context in which the situation is placed, and the family of situations allows the person to make sense of the situation;

2. The baggage / experimental field available to the person or group of persons involved in the treatment of the situation is determined for the development of competence; this experimental baggage consists of the person's knowledge;

3. Competence development is based on the mobilization and coordination by the person of a variety of resources: the person's own resources (from the 
previous experimental baggage), resources specific to certain circumstances of the situation and external resources of the person, situation and context;

4. Competence is the result of a time, complex, dialectical and constructive process of dealing with the situation.

In conclusion, we can conclude: competence is always the result of a time, complex, dynamic, dialectical and constructive process of dealing with the situation.

The reason for the lack of a generally accepted definition of competence is the complexity of this notion. In this context, it can be said with certainty that the key element in the definition of competence is attitude. It guides, motivates and makes possible the performance in musical education. In the view of the researcher Vl.Pîslaru the competence is the generic term for the projected educational value (objective), which in the educational-didactic process gradually integrates into the acquisition of the educator (finality), having a triadic insectile structure, manifests in various levels of development, the age of the child, the quality of education, and the general orientation of becoming one for one's own being.

M.Morari emphasizes that musical competence is an integrated set of knowledge, skills and attitudes developed in the training process and mobilized in certain situations, taking into account the age and intellectual level of the student, directed to solving the specific problems of life, stemming from the system of prevailing values in national culture and universal music [6, p. 23]. In this context, the typology of specific competencies is largely in relation to the classification of specific areas of Musical Education:

1. They are multifunctional: they participate in solving a variety of life, social and didactic issues;

2. They are multidimensional: they train different cognitive processes and intellectual capacities.

Thus, the stage of process development is characterized by concrete operations of thought and the beginning of formal operations. In small classes some students may be able to work with abstractions, but most of them need generalizations based on concrete experiences. All the elements of music in the process of forming can take the name of musical knowledge / capabilities / attitudes, this quality gives them a unitary character that works for the formation of musical skills. D. Hopkins and M.Ainsow point out that since changes in training are not maintained to the point of exerting effects on students, we will have to recognize that investing is specifically in staff development, not in improving student performance [1, p. 51]. CM training must therefore be carried out according to models specific to the artistic and aesthetic knowledge, the selection of which should be based on certain criteria:

$>$ the degree of suitability to the specific subject of Musical Education;

$>$ converting the general patterns of individual training to the principles of musical education: specific reinterpretation [3, p.70], correlation of musical education with life, unity of education, training and musical development;

$>$ Interaction of macronihic components specific to musical skills. 
Reference sources define competence as a fullness of knowledge, abilities, attitudes, which are manifested in the solution of a problem, the fulfillment of a role, a function, or the expression of a state. Competences are also defined as knowledge that became operational by M.Calin [2, p.64], I.Jinga and E.Istrate [4], etc., as an intellectual capacity with transfer possibilities and associated with components affective and attitude, motivating the action - by P.PopescuNeveanu [6]. Most authors mention for their knowledge the ability to be operational and to express attitudes, which is epistemologically demonstrated in this basis by Vl.Pslaru, which mentions this quality as being characteristic to the greatest extent of the artistic-aesthetic knowledge, thus also of the musical [ 2, p.43].

In this context, adhering to the beliefs of the scholars mentioned in the research, the elaboration of the typology of musical competences was based on the processuality of the musical-artistic knowledge (B.Asafiev, I.Gagim, etc.). Impulse / form (the aspect of perceiving the musical message, the stage of primary knowledge) is a evocation, that is, knowledge is a theory. The musical impulse is concretized as the first vibration / sensation that appears discreetly and involuntarily in the psychic depths ascending to the surface to obtain the musical form, that is the foundation in every attempt to know the music. When we refer to development as a procedural element of music, this means that theoretical knowledge can become functional if it is applied practically (aspect of understanding, application, synthesis), so this is the mechanism of converting the theoretical knowledge into a practical form - in capacity.

Only through the practical applicability of musical knowledge in the musical-didactic activities: audition, creation, interpretation, reflection, the necessary competences are formed, respectively, we refer to the functionality of the musical competences. When we refer to the ending element, in the process of musical-artistic knowledge, functional knowledge becomes atudine, the behavior, the affectivity of the student. The internalized psychological form of skills is the attitudes, behaviors, the student's / student's attitudes towards musical art.

The perception / reception of music is considered the basis and essence of musical activity. In his researches, I.Gagim has established and characterized three general levels of musical perception: [3, p.88] (a) philosophical: music works on elementary senses - pleasure-disgust, excitement-tranquility; (b) psychologically: the artistic message is perceived, the sound is transferred to the psychological, the external movement becomes internal (imagistic); (the imitation is indispensable to the human being, facilitating the act through the courage gives logical meaning and meaning to the experiences, making it possible not only to live but also to relive the events); [4] (c) Spiritually: music communicates with the whole subject, the energy of music tending to exteriorize in action, perception and knowledge of music.

By analyzing the theoretical and methodological sources, we have found the universal character of musical competences, investigating the classifications of different historical epochs of notorious personalities of the field, and from the 
perspective of the main fields on which the Music Pedagogy (Psychology of Music and Musicology) is founded. As I mentioned, the process of teaching and training musical knowledge in students involves not only their traditional / classical treatment, but also from the dynamic perspective of the inner processes between the elements of music.

So, for a perspective view in the process of musical skills training, it is the treatment of $\mathrm{CM}$ as functional systems that facilitate the reception / understanding / learning / assimilation of content as an important stage in the experience of the artistic phenomenon, respectively the formation / development of the domain competences. Therefore, the processuality in artistic and aesthetic knowledge based on fundamental, gnoseological, epistemological concepts in the knowledge of reality, musical knowledge and classification of musical competences (Aristotle, I.Kant, G.Hegel, B.Asafiev, Gh.Orlov, E.Nazaikinski , V.Bobrovski, L.Mazeli, V.Meduşevki, V.Pslaru, I.Gagim, M.Morari) determined the re-conceptualization on the inside and the re-thinking of the typology of CM according to the specific principles of training the musical skills in pupils in the musical-didactic activities of the lesson.

According to the Efficiency Standards of Music Education in Primary and Secondary Education of the Republic of Moldova (2011), we mention that the standards elaborated in the document proposed by the Ministry of Education of the Republic of Modova take into account the necessary training and evaluation skills specific to the Musical Education discipline and are formulated accordingly the four musical fields considered compulsory for general education: basic musical creation, musical interpretation (vocal-choral and musical instruments for children, reflection). This kind of understanding of musical competences has led us to classify specific competence in:

$>$ Music competences in the I-Audience field;

$>$ Musical competences in the field II - Musical interpretation;

$>$ Musical competences in field III - Musical creation;

$>$ Musical competences in the field of IV - Reflection.

\section{Conclusions}

Music competences specific to Music Education are characterized by the level of attitude and behavioral behavior specific to the music recipient. In the psychological, philosophical and pedagogical literature according to the researchers (J.Piaget, L.Thurstone, G.Allport, A.Chircev, V.Measiscev, D.Vrabie, Vl.Pâslaru, I.Gagim) there are both cognitive elements as well as emotional and behavioral elements. The cognitive and affective components of attitude are those that determine the awareness and meaning of the subject-toobject relationship. Therefore, in the value / aesthetic appreciations given to a musical creation, the actual behavior of the subject of education in the musicaldidactic activities of listening, interpretation, creativity marked by reflection is fully engaged both in the intellectual sphere and the emotional. Based on these findings with reference to the issue, we mention that the basis of the inner and outer mechanisms are emotional experiences [7, p.77]. 
Specific competencies include several intimately linked and interdependent elements: musical consciousness, beliefs about music, appreciations, valorizations that result from the pupil's concept of life, from his system of values.

\section{Bibliography}

1. Concepția educaţiei în Republica Moldova. (2000), Editura Lyceum, Chișinău. p. 9

2. Cotoviţchi, D. Hubenco, T. Prisacaru L. (2011), Educația plastică. Ghid de implementare a curriculumului modernizat pentru învățămîntul primar și gimnazial. Editura Lyceum, Chișinău, 2011. p.5

3. Educația muzicală (2000), Curriculum școlar. Clasele V-IX/Ministerul Educației. Coroi E., Croitoru S., Borș A., Gagim I. Editura Cartier, Chișinău. p.7 4. Educația muzicală. (2010), Curriculum Național pentru învățămîntul gimnazial. Clasele a V-a - a VIII-a/Ministerul Educației. Morari M., Stîngă A. Editura Lyceum, Chișinău, 2010. p.5

5. Educație artistică. (2000), Ghiduri metodologice. Grupul editorial Litera, Chișinău. p. 5

6. Educație plastică. (2000), Curriculum școlar. Clasele V-VII/Ministerul educației. Daghi, I. Ciobanu, S. Malcoci, V. Ursu, Z. Editura Cartier, Chișinău. p.3

7. Gagim, I. (2003), Dimensiunea psihologică a muzicii. Iaşi. p. 159 